\title{
FACTORS CONTRIBUTING AND PROMOTING OPEN INNOVATION IN INDIAN FEMALE-OWNED FOOD PROCESSING SMES- PRIORITIZING THROUGH THE AHP TECHNIQUE
}

\author{
Supriya Lamba Sahdev \\ Amity International Business School, Sector-125, Amity University \\ Noida, UP, India, slamba@amity.edu \\ https://orcid.org/0000-0001-5141-5538 \\ Gurinder Singh \\ Amity International Business School, Sector-125, Amity University \\ Noida, UP, India, gsingh@amity.edu \\ https://orcid.org/0000-0002-7827-1578 \\ Navleen Kaur \\ Amity International Business School, Sector-125, Amity University \\ Noida, UP, India, nkaur@amity.edu \\ https://orcid.org/0000-0002-6814-5690
}

Article history: Received 29 September 2021, Received in revised form 2 October 2021, Accepted 5 October 2021, Available online 5 October 2021

\begin{abstract}
The prime motivation behind this investigation is to recognize and organize the different factors connected to Open Innovation in the already up and running from last five years Indian female owned SMEs in Food Processing Industry. Fifteen Indian female owners were chosen. An AHP system was utilized to examine the weight of basic elements leading towards Open Innovation. All things considered, the respondents organized advancement technique, opportunity acknowledgment, money and inspiration as the principle criteria that leads to Open Innovation in Indian females owned SMEs in Food Processing. COVID-19, gender gap, raising inner and outer funds were likewise observed as a hindrance ladies face that usually would keep them away from innovative tasks performed for business. The result of this examination is giving policymakers in India food for thought regarding the significance of the factors connected to development of Indian female owned SMEs in Food Processing Industry and will be able to move towards sustainable development goals- Goal 9 (Industry, Innovation and Infrastructure) and Goal 5 (gender equality) which is required for the economic development of the country. This will assist them with systemizing and organizing the basic, advancement of open innovation factors in Indian female owned Food Processing SMEs, which will give a boost to the contribution of Indian females in the financial development of India, which a developing country currently.
\end{abstract}

\section{Keywords}

open innovation; India; SMEs; female owned Food Processing SMEs; AHP.

\section{Introduction}

Business has for quite some time been known as a driver of financial development. Innovation based SMEs are a pointer of a sound and developing economy [1], subsequently, such undertakings ought to be energized, bolstered, and developed to the best conceivable degree [2] especially in developing countries like India. In India, nearly 453,339 SMEs structure the centre of the India government's development methodology [1]. A study by McKinsey estimated in 2015 that promoting women's equality in India can make the GDP boost by \$0.7 trillion in 2025. Also, entrepreneurship is an underdeveloped area to work upon the economic potential of women in India, which will further help in achieving the sustainable development goals: Goal -9 (Industry, Innovation, and Infrastructure) and Goal-5 (gender equality) [3] Indian history is a proof that India was a male's dominated zone [4]. According to Sixth Economic Census by National Sample Survey Organization (NSSO), out of 58.5 million businesses, in India 8.05 million business are owned by females. The critical development of female owned and managed SMEs in creating nations has drawn the consideration of both scholastics and the corporate segment [5]. Worldwide open foundations, national and governments, NGOs, privately owned businesses, philanthropies, 
information foundations and business affiliations have started projects and approaches to advance and create female enterprise [1]. As per the Mastercard Index of Women Entrepreneurs (MIWE) 2018, in 2016 around 163 million women in 74 economies started new businesses in the world and approax 8 million women are running their own businesses. India is world's second - largest producer of vegetables and fruits. Out of India's food market, 32\% accounts for processing of food and in terms of manufacturing, consumption, exporting and expected growth, which ranks $5^{\text {th }}$. In Manufacturing and Agriculture, it contributes 8.83 and $10.66 \%$ to Gross Value Added respectively. In 6 years ending 2017-18, Food Processing Sector in India grew at an AAGR of around $5.06 \%$ [6]. And contributes $13 \%$ to exports. Indian government aims to support the food processing sector by leveraging reforms like $100 \%$ FDI in marketing of food items and exemptions and support system at central and state level with a focus on infrastructure required for supply chain. As per DIPP, in India the food processing sector has received around US\$ 7.54 billion worth of FDI during the period April 2000 -March 2017 [7]. The Indian Food Processing industry has been growing at an Average Annual Growth Rate of $8.41 \%$ in 2014-18. As per the data collected in Annual Survey of Industries (2016-17), food processing accounted for [8].

- $15.95 \%$ of total number of factories

- $16.78 \%$ of operational factories

- employed $11.36 \%$ of workforce

- $14.09 \%$ of output

Innovation was believed to be the domain of huge companies/ MNCs. In recent years literature has increased about innovation, SMEs, and women's owners, which throws light on positive effect of innovation on women, and about an underrepresentation of females in the areas that are related with generating innovation. This Study throws light on the components that support and block Indian female businessowners from being increasingly adopting Open Innovation, for example, assembling, science and innovation. Limited research has been done to investigate these components in Female businessowners in Food Processing SMEs [9]. This examination looks to accomplish the following exploration goals:

a. distinguish the inhibitors and facilitators that advance Open Innovation development in Indian women owned Food Processing SMEs.

b. organizes the significance of chance acknowledgment, culture, innovation, aptitudes improvement, development system, inspiration, government approaches, fund, and factors in already up and running Indian Female owned Food Processing SMEs.

For understanding the status of open innovation Indian Food Processing SMEs owned by Females numerous factors, sub-factors were identified and then exploration was planned by forming a multi-criterion diagnosis and a levelled process (AHP) model, by utilizing subjective factors and sub-factors which are on a lateral stage converted into quantitative pointers which further help female owners in better understanding [10].

\section{Literature review}

1. Open Innovation (OI)

Innovation may include growing new items, new strategies for creation, new sources of supply, the abuse/exploitation of new markets, or new approaches to compose business [11]. Open Innovation is a process of progressively arranged procedure of innovation in which organizations benefit from outer information is called 'open innovation', a worldview that expect that associations can and should consolidate inner thoughts, outer thoughts and ways to advertise, as associations hope to propel their innovations [12]. It is evident from prior research that engaging in OI helps firms to access ideas, knowledge and technologies from relevant stakeholders in their ecosystems [13]. The ability of Indian SMEs is colossal and can coordinate with its remote partners, yet it is obvious that they slack in development. Adoption of innovations in SMEs can support the Food Processing Sector of India and can make Indian SMEs comparable to already developed nations [14]. Firm size has been found to impact OI practices and outcomes [15]. Hewitt-Dundas and Roper (2018) [16] identify that levels of $\mathrm{OI}$ in small firms are sub-optimal due to a paucity of OI capabilities. The current literature on SME$\mathrm{OI}$ is thin and fragmented [17]. Empowering female business owners in the food processing industry will expand the way of life and contributes towards the making the economy more developed [18].

2. Opportunities and challenges faced by female entrepreneurs in India As per APJ Abdul Kalam, "empowering women is important for making a country decent as this leads to better family, society and nation". Indian women owners are important for Indian economy as they contribute $3.09 \%$ to industrial output and give $10 \%$ jobs in various industries [19]. But in India, women owned SMEs, have lack of access to capital which is the biggest constraint for them in making their businesses run [20]. In 2014, Prime 
Minister Modi's Make in India was launched and focusing on MNCs and more FDI in India and missing on women's entrepreneurial capabilities. Whereas, $8 \%$ of manufacturing is from the Indian SME sector. Women hold a fair stake (14\% of registered enterprises, $9 \%$ unregistered) among SMEs. Two industries were highlighted in the Make in India campaign including the garment and food processing which are popular among women entrepreneurs. $10 \%$ share of women's entrepreneurship is there in food processing, which is no doubt is low and the potential remains unexplored [21]. The Statewise female owned MSMEs in India (per 1000 MSMEs) - Andhra Pradesh 247, Arunachal Pradesh 276, Assam 55, Bihar 49, Chhattisgarh 84, Delhi 93, Goa 154, Gujarat 249, Haryana 101, Himachal Pradesh 129, Jammu \& Kashmir 106, Jharkhand 196, Karnataka 244, Kerala 208, Madhya Pradesh 138, Maharashtra 168, Manipur 481, Meghalaya 351, Mizoram 392, Nagaland 229, Odisha 149, Punjab 153, Rajasthan 141, Sikkim 193, Tamil Nadu 260, Telangana 373, Tripura 133, Uttar Pradesh 96, Uttarakhand 50, West Bengal 327, A \& N Islands 210, Chandigarh 99, Dadra \& Nagar Haveli 169, Daman \& Diu 202, Lakshadweep 260 and Puducherry 283 [22]. Females have been known to have unprecedented innovative abilities that empower them to prevail in various organizations [2,23]. Gupta and Agarwal (2017) [24], detailed that Indian ladies faces hindrances which includes paucity of career obligations, lack of monetary instability of ladies, risk taking capacity absenteeism, managing finance \& raw material, tough competition, low degree of proficiency among ladies, getting help by banks, marketing issues, no help from family, and significant cost of production. From Indian Food Processing Industry, we have examples of successful females, owing and managing SMEs like Monica Narula-Idea Chakki Private Ltd., Lisa Suwal-Prasuma Meats \& Delicatessen, Dipti Motiani- Freshtrop Fruits Ltd., Rupali Bhatnagar-Sparkling Wines, at Sula Vineyards and Anamika Singh- Anandini Himalaya Tea [7]. To get a reasonable image of the difficulties faced by Indian female owned Food Processing SMEs doing Open Innovation, this investigation utilizes the accompanying classifications: culture, inspiration, strategy of open innovation, opportunity acknowledgment, finance, technology, expertise development and policies of Indian government.

Culture - Societal and cultural characteristics qualities are profoundly powerful in deciding enterprising achievement as per Baum and Locke (2004) [25] and Gutcher (2013) [26] as Thornton et al. (2011) [27] saw culture as an example of reasoning, acting, and feeling; such factors are not specific to a country [28]. Distinguished social qualities and cultural qualities as key properties of culture [27]; these qualities have an immediate connect to business enterprise. Social qualities allude to the esteem framework received by individuals inside a typical social setting, which is described by basic standards, family structure and frames of mind legitimately identified with imaginative direction [29]. Creating inventive culture in SMEs prompts showcase situated, client cantered, and provider arranged items and forms that encourage elite of SMEs [30,31].

Inspiration - Lim, Wadhwa and Mitchell (2010) [31] study distinguishes top five money related and mind elements inspiring ladies to start their businesses. The difficulties are more related with business enterprise as opposed to gender [32]. The part of inspiration assumes a focal function in advancing SME innovation [33].Family and friends help are the prime factors to contribute towards inspiration [18]. This reflects Indian culture and its people and the effect of family members and relationships on the choices being made by the female owners in the Indian Food Processing SMEs. And no doubt inspiration plays a prima facie role promoting innovation in SMEs (Vijayakumar et al., 2013) [34].

Strategizing for innovating - For Indian Food Processing SMEs, innovation is a way towards development, improving and executing in a better manner $[35,36]$. Businesspeople must stay mindful of new market patterns and track their rivals progress to beat their partners [37]. Open innovation can be actualized by leading studies or meetings with clients, providers, workers, investigate associations and colleges to create new thoughts and open ways to new openings [38]. Also, in developing economies like India, the historical role of women in entrepreneurship and patenting endeavours, and the barriers to greater female participation in innovation in STEM (science, technology, engineering, and mathematics) fields has been focused on [39].

Acknowledging the opportunities available - It is the prime and the most significant thought or idea behind research done in entrepreneurship research and in the way forward towards the process of Innovation [40]. The opportunity available in the Indian food processing SMEs is perceived by watching closely, testing the idea or information, and abusing/converting that into something that can be commercialized from the perspective of innovation in different SMEs, even rival firms and market top performance firms [41]. 
Finance - There is a dire need to address gender discrimination in the small-business credit market will help in bridging the performance gap between male and female-owned firms in India [42]. Around 79\% of women owned businesses are self - financed, as families are usually hesitant to support their daughter's entrepreneurial ventures financially [43]. Arranging the finance required is considered to be a vital factor and no doubt is the largest obstacles faced by the Indian Food Processing for innovating. World Bank Enterprise Survey recognized the likely endogeneity of gender in credit constraints [44]. Enterprises owned by female entrepreneurs are on average $3 \%$ less likely to be credit constrained compared to their male counterparts [33].

Technology - To improve competitiveness of Indian Food Processing SMEs, government should make more efforts to encourage foreign investments and IT service providers and come up with business environment related economic policies. These efforts by government will help in making efficient ICT applications for sustainable growth of SMEs. The web is a stage for development which helps SMEs in advertising, making openings and getting to showcase patterns [37]. Cloud computing is another type of innovation which extremely engaging SMEs because of its cost adequacy, is greatest ROI and intensity in a business domain [45]. Informal communities have brought new open doors for SME administrators in both created and creating districts $[5,35]$.

Development of Expertise - Gaining prodigy or development of expertise in skills is the prime factor that helps in promoting innovation in the Indian Food Processing SMEs which are women owned. India is enjoying a demographic dividend vis-à-vis countries with rapidly ageing population [46]. The National Skill Development Policy (2009) envisaged the creation of 530 million skilled workers by 2022. The Skill Development Policy 20122017 are there to develop the skills of the indigenous people of the state and offer better employment opportunities [47]. Innovative, creative, and technical skills set combination is important for individuals to utilize the ideas and go for problem solving as per Singh and De Noble (2003) [48]. The already existing literature reflects that skills like leadership and good communication also help in having best objectives to be set for the firm along with best strategies adoption and execution [49]. Minister for Food Processing Industries, Smt. Harsimrat Kaur Badal launched the PM Formalization of Micro Food Processing Enterprises (PM FME) scheme on 29th June 2020 as a part of "Atma nirbhar Bharat Abhiyan". Union Minister said that the Scheme would generate total investment of Rs 35.000 crore and generate 9 lakh skilled and semi-skilled employment and benefit 8 lakh units through access to information, training, better exposure and formalization [50].

Government policies - Governments across the globe as well as varied developmental organizations are actively endeavour promotion of women entrepreneurs through numerous schemes, incentives and promotional measures [51]. Government of India has 27+ schemes for women operated by different departments and Ministries. Few of them are: Integrated Rural Development Programme, Khadi and village Industries Commission, Training of Rural Youth for Self-Employment, Prime Ministers Rojgar Yojana, Entrepreneurial Development Programme, Management Development programmes, Women's Development Corporations, Marketing of NonFarm Products of rural Women, Assistance to Rural Women in Non-Farm Development, Traded Related Entrepreneurship Assistance Development [52]. MSME Definition Further Revised to Energise MSMEs With Entire Gamut of 'Atmanirbhar Bharat Package' on $1^{\text {st }}$ June, 2020 [53].

Table 1. MSME Definition Revised in June 2020 by Government of India.

\begin{tabular}{|l|l|l|l|l|}
\hline Category & $\begin{array}{l}\text { Old Capital } \\
\text { [crore] }\end{array}$ & Old Turnover & New Capital & New Turnover \\
\hline Small & 5 & 2 & 10 & 50 \\
\hline Medium & 10 & 5 & 50 & 1 \\
\hline
\end{tabular}

3. Innovations brought by women in the SME sector

Women's entrepreneurial innovativeness is majorly impacted by the type of business, its location, and size of usiness along with age and education of the female owner [51]. As per the examination performed by Global Entrepreneurship Monitor (2015) on female business owners - it was recognised that women entrepreneur's numbers Worldwide has rose by 6\% [47]. Despite the obstructions, three associations - Shri Mahila Griha Udyog 
Lijjat Papad established in 1959, Self Employed Women's Association (SEWA) established in 1971, and Biocon40 established in 1978 - were established by ladies. In India under the existence and prevalence of gender gap, female business owners are comparatively more innovative than male partners [1]. In India, according to GEM review 2017-2018, announced that Indian Women entrepreneurs have negligible contribution in the cuttingedge segment. This might be because of following reasons, for example, a higher level of hazard and a more significant level of costs identified with mechanical development.

4. Overview of AHP

AHP is a strategy to organizing the achievement components of SMEs [54]. AHP is one of the most prevalent techniques utilized for multi-criteria decision-making. It is too flexible, handles complex issues, makes an interpretation of human pairwise decisions into analysable subjective information, and manages subjective criteria. The principle commitment of AHP is dispensing with any inclination that could be natural from esteem decisions and giving outcomes that are both predictable and powerful. This methodology has given progressively steady and reasonable information because of the interrelated correlation among factors. To choose the components that support and block Indian female businessowners from being increasingly adopting Open Innovation, this examination paper utilizes the AHP procedure. Considering the rules proposed by Saaty [10] an AHP system was created for encouraging the examination [24]. Figure 1 shows a stream outline including different strides to lead the AHP study. This study is therefore performed to identify and prioritize in order of importance the factors and sub factors that are associated with women - owned Indian Food Processing SMEs and AHP model has been used to throw light on and for having a better understanding on open innovation in India's context.

5. Research model and methodology

The key focus in this segment is on the calculated structure of this study. Under this study, following prime factors that contribute towards adoption of open innovation as facilitators are being investigated in the context of up and running (more than 5 years) female owned Indian Food Processing SMEs-culture, inspiration, strategizing for innovating, acknowledgement of the available opportunities, finance, technology, skills development, and government policies [47]. For this reason, a study based subjective and quantitative technique was utilized. With the help of the LinkedIn, 15 questionnaires were shared and 11 were answered completely and correctly in Delhi NCR. A questionnaire was utilised to acquire the reactions of up and running (more than 5 years) female owned Indian Food Processing SMEs on the hurdles underwent by them while performing open innovation. The questionnaire was created in English and included both open-ended questions utilizing a nine-point proportion scale (Table 3).

Table 2. Random index.

\begin{tabular}{|l|l|l|l|l|l|l|l|l|l|l|}
\hline $\mathrm{N}$ & 1 & 2 & 3 & 4 & 5 & 6 & 7 & 8 & 9 & 10 \\
\hline $\mathrm{RI}$ & 0.00 & 0.00 & 0.58 & 0.90 & 1.12 & 1.24 & 1.32 & 1.41 & 1.45 & 1.48 \\
\hline
\end{tabular}

Note: Where $\mathrm{n}$ is number of factors. 


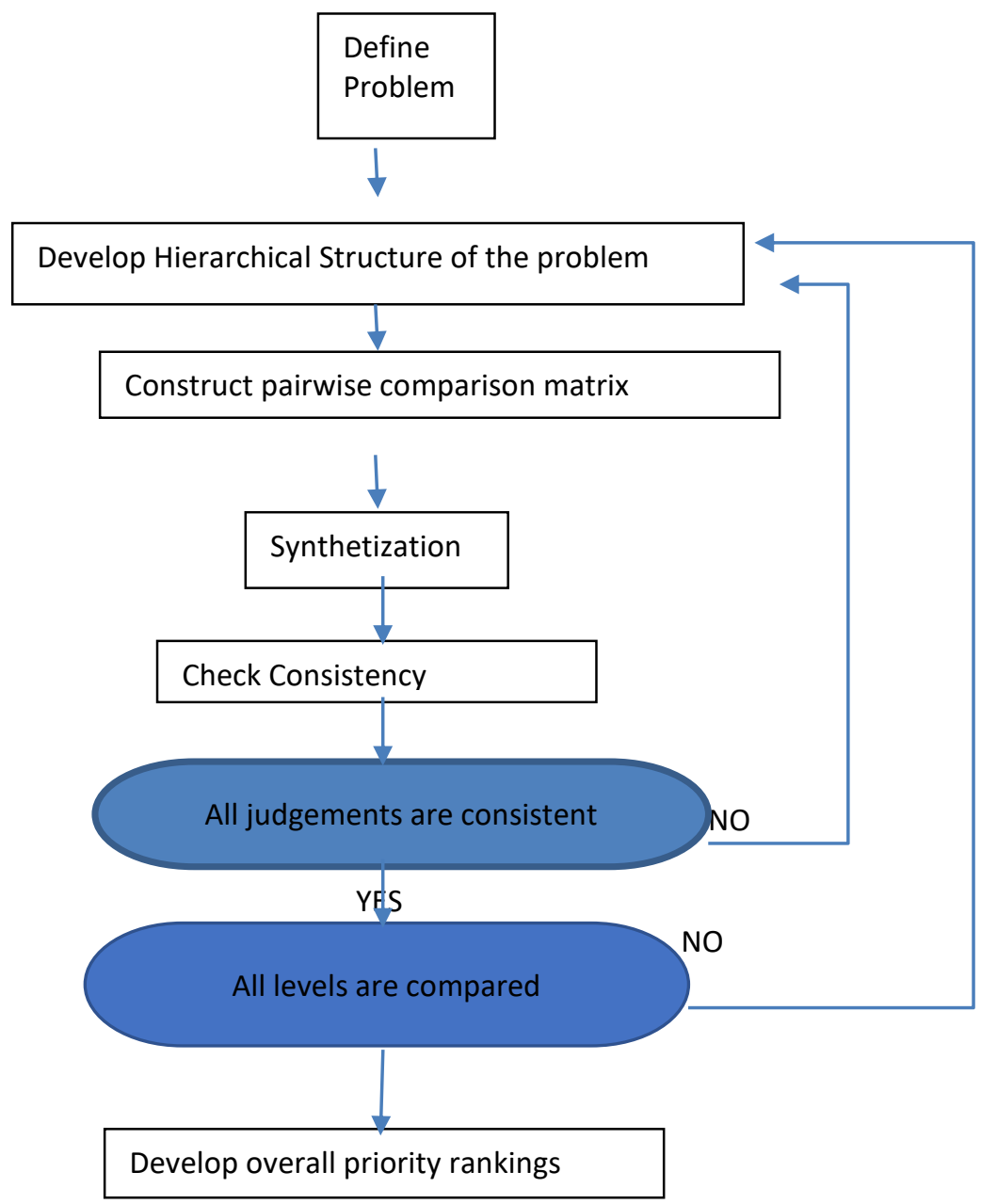

Figure 1. Follow of the AHP method (used under the study).

Table 3. AHP preferences - One to nine scale.

\begin{tabular}{|l|l|l|}
\hline $\begin{array}{l}\text { Prioritizing as per } \\
\text { their intensity of } \\
\text { importance }\end{array}$ & Definition given & Explanation made \\
\hline 1 & Importance equally shared & Equal contribution by two criteria \\
\hline 3 & Importance moderately shared & $\begin{array}{l}\text { The slightly more importance is given to one } \\
\text { criterion in comparison to the other. }\end{array}$ \\
\hline 5 & Importance - strong & $\begin{array}{l}\text { Strong importance and favour are given to one } \\
\text { criterion. }\end{array}$ \\
\hline 7 & $\begin{array}{l}\text { A super strong importance and favour is given to } \\
\text { one criterion. }\end{array}$ \\
\hline 9 & $\begin{array}{l}\text { Importance of highest possible degree is given } \\
\text { to one criterion over the other available. }\end{array}$ \\
\hline $2,4,6,8$ & Values shared between criteria's & $\begin{array}{l}\text { Represents adjusted or compromised values } \\
\text { shared between the criterions or priorities } \\
\text { mentioned in the table above. }\end{array}$ \\
\hline
\end{tabular}


Because of COVID-19 pandemic, the questionnaire was shared with the respondents through emails and messages on LinkedIn: out of the questionnaire filled and returned, 11 were finished and returned, giving a $67 \%$ reaction rate. The definition of the AHP hierarchy system was trailed by the information gathered from women entrepreneurs in established organizations. 15 respondents for this examination was utilized [55,56]. The AHP procedure incorporates foundation of a various levelled structure, characterizing loads and amalgamation [57]. An exploration issue is placed into a various levelled structure: level 1 throws light on the goal, level 2 reflects the variables of respondent's choice, whereas level 3 contains sub-variables of choice and level 4 contains the choices for where the choice is to be actualized. The loads are characterized by gathering information to gauge criteria and sub-criteria, and prioritization is led by appointing a number from a scale created by Saaty speaking to the significance of the criteria. In accordance with Saaty's (2012) [55] recommendations, a geometric mean methodology was favoured over a number juggling mean methodology to join the individual pairwise correlation decisions to get the agreement pairwise examination judgment networks for the whole group. These traits were placed in a grid structure with pairwise correlation with compute mean and integrating the last assessment of choices execution based on positions of criteria and sub criteria [10]. As reflected in Figure 1, the set stages in the AHP was the basis for the pairwise analysis of the said criteria. For characterizing pairwise examinations, Saaty (2012) proposed a nine-point proportion scale as appeared in Table 3.

a. consistency index $(\mathrm{Cl})$ was applied to calculate consistency. Saaty (1980) characterized this specific consistency $(\mathrm{Cl}=\lambda \max -\mathrm{n} / \mathrm{n} 1)$.

b. where max is the greatest Eigen estimation of the matrix of the ratios reflecting importance and $\mathrm{n}$ is the quantity of variables. At that point, the consistency proportion (CR) was utilized to survey if a grid was adequately reliable. This is the proportion of the $\mathrm{Cl}$ to the random index (RI), which is the $\mathrm{Cl}$ of a matrix of randomly created matrix ( $\mathrm{CR}=\mathrm{Cl} / \mathrm{RI})$.

C. pair wise random examinations were done to deliver average random indices for various estimated matrices. The estimations of RI are given in Table 2 [58]. As per Saaty [58], if the estimation of CR is less than or equivalent to 0.10 , the inconsistency can be acceptable.

d. Saaty [59] presented a 'consistency principle' for ascertaining priority vectors. The consistency rule says that aik = aij.ajk and further for utilizing the uncommon case of the consistency matrix framed by components aik = wi/wj, where wi and wj are the components of the priority weight vector comparing to standards and $\mathrm{j}$. The information gathered were cleaned to make sure there are mistakes, for example, inadequacy or wrong reactions. The questionnaire was created utilizing a nine-point proportion scale and an AHP strategy was utilized to rank the components that influence Open Innovation in Indian Female owned food processing SMEs. 


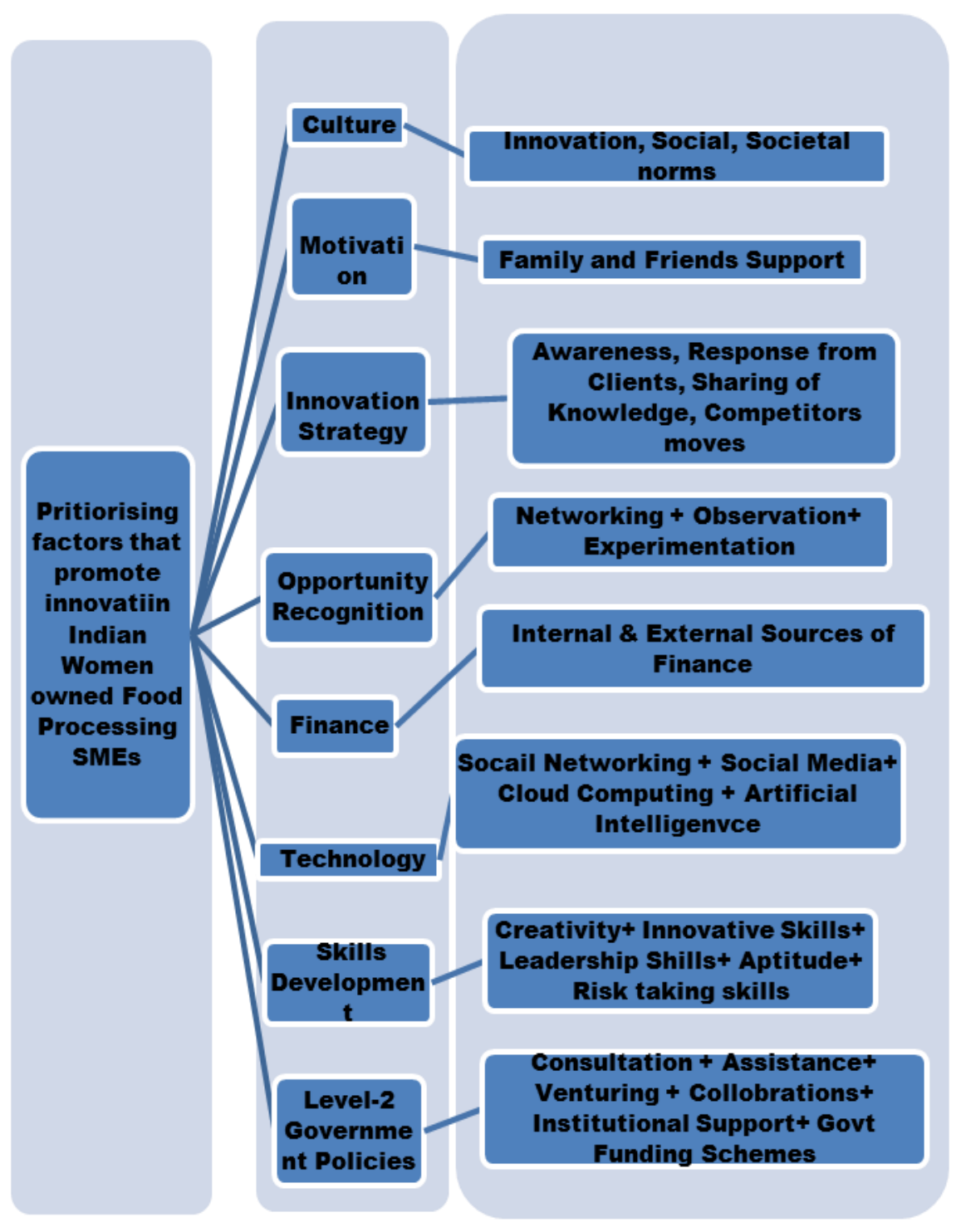

Figure 2. Model Proposed with AHP Technique.

Results and discussion

$\underline{\text { AHP analysis }}$

Criteria level analysis-In this part of the study, the AHP analysis was used to record the priorities of Indian female owned food processing SMEs. Analysis of variables/factors impacting open innovation taking place in the Indian food processing SMEs respondents are reflecting in Table 4. 
Table 4. Factors affecting Open innovation in food processing SMEs in Delhi-NCR owned by females. (CR value $=0.1)$.

\begin{tabular}{|l|l|l|}
\hline Criteria & $\begin{array}{l}\text { Established Indian Women owned Food } \\
\text { Processing SMEs }\end{array}$ & Ranking \\
\hline Societal /Culture characteristics & 0.03 & 7 \\
\hline Inspiration & 0.27 & 1 \\
\hline Strategizing for innovating & 0.22 & 3 \\
\hline $\begin{array}{l}\text { Acknowledgement of opportunities } \\
\text { available }\end{array}$ & 0.17 & 2 \\
\hline Finance required & 0.11 & 4 \\
\hline Technology status & 0.08 & 5 \\
\hline Development of Skill Sets & 0.06 & 6 \\
\hline Supporting policies of Government & 0.06 & 6 \\
\hline
\end{tabular}

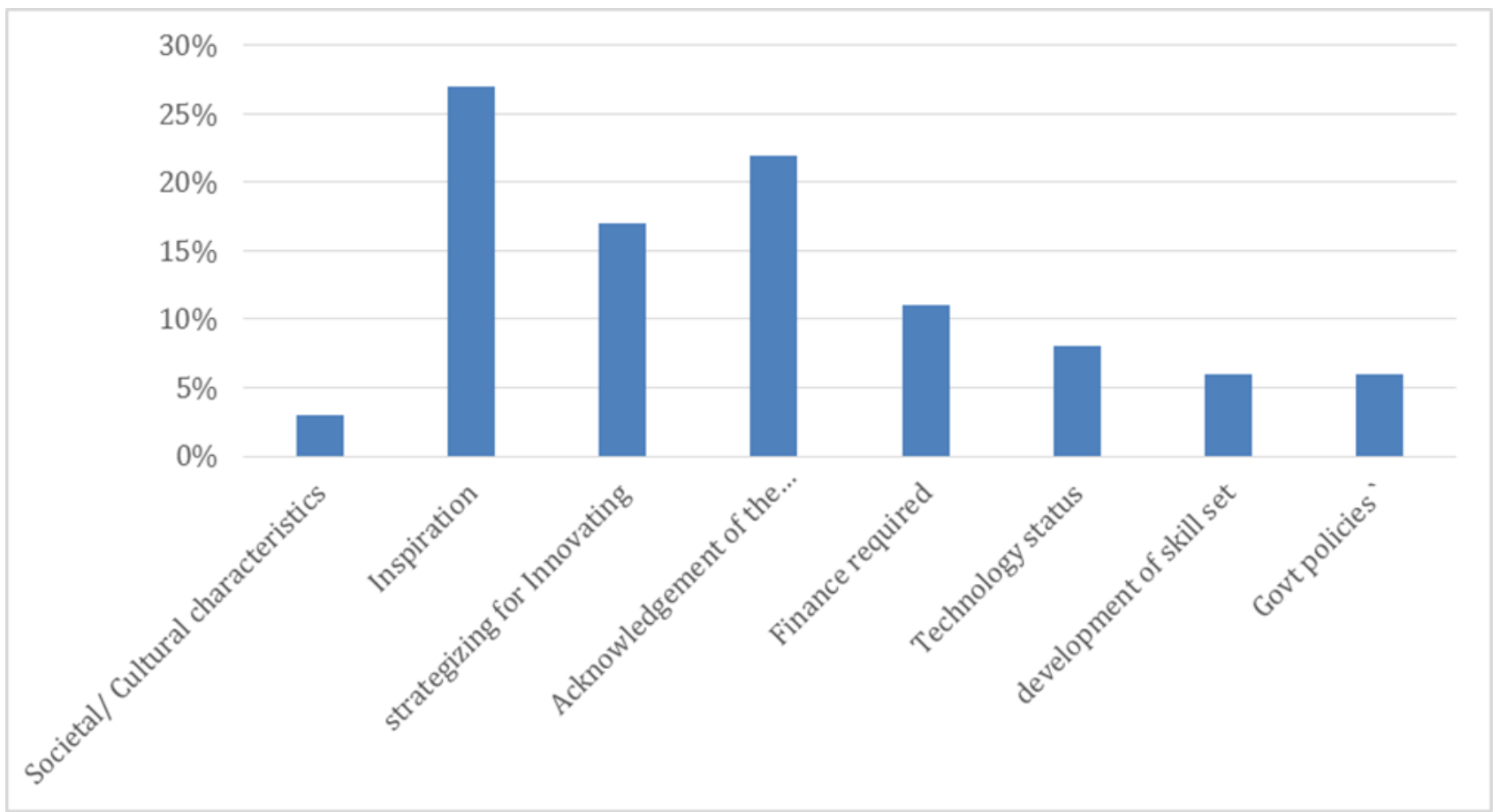

Figure 3. Criteria in up and running (already existing from last 5 years) Indian Food processing SMEs in Delhi-NCR.

From Figure 3, we can make out that all the respondents of the study were selected from already up and running Indian Food processing SMEs in Delhi-NCR (purposive sampling was done) considered inspiration as the criteria of their priority (at 27\%), with acknowledging the available opportunity as their second and innovation strategy as their third priorities at $22 \%$ and $17 \%$, respectively. All the criteria for promoting Open innovation in SMEs among Indian Food Processing female owned, by all 11 participants of the study from the already up and running Indian Food processing SMEs in Delhi-NCR, showed an accepted level of consistency with CR $=0.10$.

AHP Sub-criteria level analysis

Under this study, majorly twenty-three sub-factors/criterion were fetched from the main eight factors. Afterwards the informants from the up and running female owned Indian Food Processing SMEs were asked to prioritise these factors. In Table 5, informant's data was summarised which reflects that societal/cultural environment for innovation as their topmost priority at seventy-two \% among the sub-factor criteria. Under the main factor criteria of Inspiration, members of the family were prioritized and attained eighty-eight \%. From this it is evident that in the Indian setup, members of the family and the inspiration offered by them contributes majorly for female owned Indian Food Processing SMEs. Whereas under the factor criteria of Inspiration, 
information/ knowledge/ awareness about the market trends were given most importance of sixty-four \%. On the other hand, under the factor criteria of acknowledging the opportunities available, scrutinizing/ monitoring was given importance with thirty - five \%. Informants from the up and running Indian Food Processing SMEs reflected resistance in doing experimentation and undergoing any risky venture keeping in mind the king of impact COVID-19 pandemic has made on their operations and preferred following the ideas implemented by their rivals from the same industry.

Table 5. Pairwise comparison of all sub-criteria in established-phase businesses.

\begin{tabular}{|c|c|c|c|c|}
\hline Sub-criteria & $\begin{array}{l}\text { Priority } \\
\text { vector }\end{array}$ & CR value & Total priority & $\begin{array}{l}\text { Total } \\
\text { sub-criteria } \\
\text { ranking }\end{array}$ \\
\hline $\begin{array}{l}\text { Societal/Cultural characteristics for } \\
\text { Innovation }\end{array}$ & 0.72 & & 0.09 & 2 \\
\hline Social & 0.12 & 0.02 & 0.01 & 8 \\
\hline Societal & 0.16 & & 0.02 & 7 \\
\hline Members of family & 0.88 & 0.00 & 0.11 & 1 \\
\hline Acquaintances or friends & 0.12 & & 0.02 & 7 \\
\hline $\begin{array}{l}\text { Information/Knowledge/ Awareness about } \\
\text { the market trends }\end{array}$ & 0.64 & & 0.08 & 3 \\
\hline Feedback/response from clients & 0.18 & 0.10 & 0.02 & 7 \\
\hline Sharing of Ideas/Information/Knowledge & 0.07 & & 0.01 & 8 \\
\hline Keeping a track of the rivals/competitors & 0.12 & & 0.01 & 8 \\
\hline Scrutinizing/monitoring & 0.35 & & 0.04 & 5 \\
\hline Experimentation & 0.34 & 0.06 & 0.04 & 5 \\
\hline Developing associations & 0.31 & & 0.04 & 5 \\
\hline Inside the SMEs & 0.87 & 0.00 & 0.11 & 1 \\
\hline Outside the SMEs & 0.13 & & 0.02 & 7 \\
\hline Online portals of social media & 0.60 & & 0.07 & 4 \\
\hline Cloud based computing services & 0.09 & 0.02 & 0.01 & 8 \\
\hline Usage of internet community & 0.31 & & 0.04 & 5 \\
\hline Skill set for guidance & 0.64 & & 0.08 & 3 \\
\hline Innovation and creativity & 0.22 & 0.06 & 0.03 & 6 \\
\hline $\begin{array}{l}\text { Crisis management (in COVID-19 } \\
\text { Pandemic) }\end{array}$ & 0.14 & & 0.02 & 7 \\
\hline Schemes related to funds & 0.63 & & 0.08 & 3 \\
\hline $\begin{array}{l}\text { Collaboration with other existing } \\
\text { organizations }\end{array}$ & 0.22 & 0.10 & 0.03 & 6 \\
\hline Venture association & 0.15 & & 0.02 & 7 \\
\hline
\end{tabular}

To sum up, ranking was done of all the sub-factors criteria. Members of the family and funds available from the inside sources finance were given the top priority, which was then followed by the societal/ cultural environment for innovation, sharing of ideas/ information/ knowledge about trends of the market, skill set related to leadership and finally the online portals of social media. In this study a survey was conducted with the help of the questionnaire consisting of the above-stated factors mentioned which were used to collect data from Indian Food Processing SMEs owned by women in Delhi - NCR which prioritized the hurdles in adopting Open innovation. The informants prioritized strategizing for innovating, acknowledgement of opportunities available, funding, and inspiration as the main factors for developing criteria's which promote Open innovation in SMEs owned by women in Delhi - NCR. Moreover, financial markets are far from perfect because of COVID19 , and there has been a lack of SME equity financing in India. Therefore, SMEs mainly find the capital they need through the savings and income of the owners themselves or their family members or networks. The findings show that 
Indian Food Processing SMEs owned by women in Delhi- NCR focus primarily on product and organizational innovation. In India, female entrepreneurs mostly prefer banks, among all financial providers, for their financial support. There is a definite gap between the financing provided by banks and the financing acquired by women entrepreneurs. Indian female entrepreneurs mentioned firm size, high interest rates and lack of awareness of funding schemes as their main obstacles to obtaining financing.

\section{Impact}

The resaerch done is highlighting the need of support required by female enterpreneurs and the small and medium enterprises in developing economies like India especially after the challenging times that SMEs have undergone because of COVID-19, whereby attention of government is required for reforming and introducing new policies that help and support SMEs to grow and contribute more towards the GDP of these emerging and developing.The result of this examination is giving policymakers in India food for thought regarding the significance of the factors connected to development of Indian female owned SMEs in Food Processing Industry and will be able to move towards sustainable development goals - Goal 9 (Industry, Innovation and Infrastructure) and Goal 5 (gender equality) which is required for the economic development of the country.

Furthermore, a more precise decision - making model can be achieved using fuzzy AHP methodology or ANP, where interrelationships can be made between different levels and within the same level, and more complex relationships can be generated among the categories and sub-categories. In today's world which is driven by technology, having a strategy to innovate is must, otherwise the business will come to an end. Thus, it is the need of the hour that Indian policymakers introduce and launch such policies that extend support/help to Indian food processing SMEs owned by females through training and skill development to make their business a success in these challenging times of COVID -19 pandemic. The proposed model can be useful in future academic studies and will solve complicated decision - making problems in the business sector and will be able to move towards sustainable development goals - Goal 9 (Industry, Innovation and Infrastructure) and Goal 5 (gender equality) especially when the Indian economy is so badly impacted by COVID-19. In practical terms, the study includes interpretations and discussions that will help policymakers and related associations formulate and develop policies to empower Indian female entrepreneurs and initiate Open innovation in their businesses in an effective manner. In the year 2019, India has gone from 81 in 2015 to 52 position according to Global Innovation Index (GII) [60]. Government has revised the definition of SMEs in year 2020 for the growth of SMEs in India.

\section{Conclusions}

This study examined the various factors that will promote Open innovation adoption and execution in Indian female - owned Food processing SMEs in Delhi NCR which is required for them to become economically stronger and come out of the impact of COVID-19. The AHP method of analysis was conducted with the help of the primary data collected through the survey performed based on the questionnaire shared with the 11 Indian female owners from the Indian Food processing SMEs. Prioritizing strategies for innovating, acknowledgement of opportunities available, funding, and inspiration as the main factors for developing criteria's which promote Open innovation in SMEs owned by women in Delhi - NCR. As per the informants, strategy, and cultural aspects both impact innovation to a greater extend. It must be kept in mind by the female owners to adopt and use all these in the initial stages or years of their business. COVID-19, gender gap, raising inner and outer funds were likewise observed as a hindrance ladies face that usually would keep them away from innovative tasks performed for business. The result of this examination is giving policymakers in India food for thought regarding the significance of the factors connected to development of Indian female owned SMEs in Food Processing Industry and will be able to move towards sustainable development goals - Goal 9 (Industry, Innovation and Infrastructure) and Goal 5 (gender equality) which is required for the economic development of the country. This will assist them with systemizing and organizing the basic, advancement of open innovation factors in Indian female owned Food Processing SMEs, which will give a boost to the contribution of Indian females in the financial development of India, which a developing country currently.

\section{Conflict of interest}

There are no conflicts to declare.

\section{Acknowledgments}

This research has not been supported by any external funding. 


\section{References}

[1] N. Saraf, Global Entrepreneurship Monitor 2013 India Report, 2013.

[2] I.P.W. Wijeyaratnam, T. Perera, Barriers of women entrepreneurship: SME sector in Srilanka, Sri Lankan J. Manag. 18 (2013) 51-81.

[3] McKinsey \& Company, the Power of Parity : Advancing Women's Equality in India, McKinsey Glob. Inst. (2015) http://www.mckinsey.com/insights/growth/the_power_of_parity_advancing_womens_equality_in_in dia.

[4] S. Agarwal, U. Lenka, An exploratory study on the development of women entrepreneurs: Indian cases, J. Res. Mark. Entrep. 18 (2016) 232-247. https://doi.org/10.1108/JRME-04-2015-0024.

[5] UNCTAD, Annual report, 2013.

[6] The Union Minister for Finance \& Corporate Affairs, Economic Survey 2019-20, (2020).

[7] R. Hanson, Food Processing Sector, (2011) 1-24. https://doi.org/https://ficci.in/sector.asp?sectorid=15.

[8] C. of I. Industry, Indian Food Processing Sector, New Delhi 12. (2019).

[9] D.P. Price, M. Stoica, R.J. Boncella, The relationship between innovation, knowledge, and performance in family and non-family firms: an analysis of SMEs, J. Innov. Entrep. 2 (2013) 14. https://doi.org/10.1186/2192-5372-2-14.

[10] T.L. Saaty, Decision making with the Analytic Hierarchy Process, Sci. Iran. 9 (2002) 215-229. https://doi.org/10.1504/ijssci.2008.017590.

[11] H. Bloch, The theory of economic development, in: Schumpeter's Price Theory, Harvard University Press, Massachusetts, 2020: pp. 13-23. https://doi.org/10.4324/9781315724744-2.

[12] S. Mazzocchi, Open Innovation: The New Imperative For Creating and Profiting From Technology, Innovation. 6 (2004) 474-474. https://doi.org/10.5172/impp.2004.6.3.474.

[13] A. Spithoven, P. Teirlinck, D. Frantzen, Managing open innovation: Connecting the firm to external knowledge, Edward Elgar Publishing, 2012. https://doi.org/10.4337/9781781953594.

[14] S.B. Gunjati, C. V. Adake, Innovation in Indian SMEs and their current viability: A review, in: Mater. Today Proc., 2020: pp. 2325-2330. https://doi.org/10.1016/j.matpr.2020.04.604.

[15] A.J.J. Pullen, P.C. De Weerd-Nederhof, A.J. Groen, O.A.M. Fisscher, Open innovation in practice: Goal complementarity and closed NPD networks to explain differences in innovation performance for SMEs in the medical devices sector, in: J. Prod. Innov. Manag., 2012: pp. 917-934. https://doi.org/10.1111/j.1540-5885.2012.00973.x.

[16] N. Hewitt-Dundas, S. Roper, Exploring market failures in open innovation, Int. Small Bus. J. Res. Entrep. 36 (2018) 23-40. https://doi.org/10.1177/0266242617696347.

[17] S. Popa, P. Soto-Acosta, I. Martinez-Conesa, Antecedents, moderators, and outcomes of innovation climate and open innovation: An empirical study in SMEs, Technol. Forecast. Soc. Change. 118 (2017) 134-142. https://doi.org/10.1016/j.techfore.2017.02.014.

[18] K. Naser, W.R. Mohammed, R. Nuseibeh, Factors that affect women entrepreneurs: Evidence from an emerging economy, Int. J. Organ. Anal. $17 \quad$ (2009) 225-247. https://doi.org/10.1108/19348830910974932.

[19] Government of India, Provisional Results of Sixth Economic Census All India Report, (2014).

[20] IFC, Financial inclusion for woman-owned micro, small \& medium enterprises (MSMEs) in India, Int. Financ. Corp. (2019). https://www.ifc.org/wps/wcm/connect/ca5c0868-e89d-4b43-ace58a702ed29b25/Financial+Inclusion+for+Womenowned+MSMEs.July+31.pdf?MOD=AJPERES\&CVID=mOK28X8

[21] Where are the woman in Make in India's vision?, (2014). https://www.livemint.com/Opinion/x1NJqQiCdx8bQrxE95ju6N/Where-are-the-women-in-Make-InIndias-vision.html.

[22] https://smestreet.in/infocus/195-msmes-out-of-1000-are-led-by-women-entrepreneurs-in-india/, (2018).

[23] J.M. Fielden, Grief as a transformative experience: Weaving through different lifeworlds after a loved one has completed suicide, Int. J. Ment. Health Nurs. 12 (2003) 74-85. https://doi.org/10.1046/j.14400979.2003.00271.x. 
[24] D. Maletič, F. Lasrado, M. Maletič, B. Gomišček, Analytic Hierarchy Process Application in Different Organisational Settings, in: Appl. Theory Anal. Hierarchy Process - Decis. Mak. Strateg. Decis., InTech, 2016. https://doi.org/10.5772/64511.

[25] J.R. Baum, E.A. Locke, The relationship of entrepreneurial traits, skill, and motivation to subsequent venture growth, J. Appl. Psychol. 89 (2004) 587-598. https://doi.org/10.1037/0021-9010.89.4.587.

[26] L. Gutcher, Women in UAE SMEs told to look beyond cupcakes, Natl. (2013). www.thenational.ae/business/economy/women-in-uae-smes-told-to-look-beyondcupcakes\#ixzz2wb2dg7Se.

[27] P.H. Thornton, D. Ribeiro-Soriano, D. Urbano, Socio-cultural factors and entrepreneurial activity: An overview, Int. Small Bus. J. 29 (2011) 105-118. https://doi.org/10.1177/0266242610391930.

[28] P. Arenius, A. Kovalainen, Similarities and differences across the factors associated with women's selfemployment preference in the Nordic countries, Int. Small Bus. J. 24 (2006) 31-59. https://doi.org/10.1177/0266242606059778.

[29] N. Krueger, F. Liñán, G. Nabi, Cultural values and entrepreneurship, Entrep. Reg. Dev. 25 (2013) 703707. https://doi.org/10.1080/08985626.2013.862961.

[30] P. Rujirawanich, R. Addison, C. Smallman, The effects of cultural factors on innovation in a Thai SME, Manag. Res. Rev. 34 (2011) 1264-1279. https://doi.org/10.1108/01409171111186397.

[31] D.S.K. Lim, E.A. Morse, R.K. Mitchell, K.K. Seawright, Institutional environment and entrepreneurial cognitions: A comparative business systems perspective, Entrep. Theory Pract. 34 (2010) 491-516. https://doi.org/10.1111/j.1540-6520.2010.00384.x.

[32] H.P. Bulsara, J. Chandwani, S. Gandhi, Women Entrepreneurship and Innovations in India: An Exploratory Study, Int. J. Innov. 2 (2014). https://doi.org/10.5585/iji.v2i1.2.

[33] IFC, Strengthening access to finance for women-owned SMEs in developing countries, 2011.

[34] R. Karan, S. Shokeen, Women Entrepreneurs in India - Issues and Challenges, Int. J. Econ. Manag. Stud. 4 (2017) 17-23. https://doi.org/10.14445/23939125/ijems-v4i12p103.

[35] B.R. Barringer, R.D. Ireland, Entrepreneurship: Successfully Launching New Ventures, Pearson, Harlow, 2012. http://scholar.google.com/scholar?hl=en\&btnG=Search\&q=intitle:No+Title\#0.

[36] S. Bucolo, C. Wrigley, Design Led Innovation as a Means to Sustain Social Innovation Enterprises, Des. Bus. Conf. 2011, 17-18 Novemb. 2011, IED Barcelona, Barcelona. (2011) 17-18.

[37] OECD, OECD Innovation Strategy 2015 An Agenda for Policy Action, OECD Rev. Innov. Policy. (2015) 395423. http://www.oecd.org/mcm/documents/OECD-Innovation-Strategy-2015-CMIN20157.pdf\%5Cnhttp://www.oecd-ilibrary.org/science-and-technology/oecd-reviews-of-innovation-policychina-2008/framework-conditions-for-innovation_9789264039827-12-en.

[38] U. Georgy, External Knowledge Inflow by Open Innovation in Public Libraries Potential of knowledge management in public libraries - Knowledge Management, IFLA World Libr. Inf. Congr. 2012 Helsi (2012) 1-10. http://conference.ifla.org/ifla78.

[39] C. Chatterjee, S. Ramu, Gender and its rising role in modern Indian innovation and entrepreneurship, IIMB Manag. Rev. 30 (2018) 62-72. https://doi.org/10.1016/j.iimb.2017.11.006.

[40] S. Bucolo, C. Wrigley, Design led innovation to sustain social innovation enterprises, in: J. Faust (Ed.), Bus. Des. Conf. - A Discursive Summ., CreateSpace Independent Publishing Platform, United States of America, 2013.

[41] R.A. Baron, Entrepreneurship: A process perspective, Acad. Manag. Perspect. 20 (2006) 104-119.

[42] K. Chaudhuri, S. Sasidharan, R.S.N. Raj, Gender, small firm ownership, and credit access: some insights from India, Small Bus. Econ. 54 (2020) 1165-1181. https://doi.org/10.1007/s11187-018-0124-3.

[43] A. Mathew, Making it in India, Financ. Dev. 56 (2019) 14-17.

[44] N. Wellalage, S. Locke, Access to credit by SMEs in South Asia: do women entrepreneurs face discrimination, Res. Int. Bus. Financ. 41 (2017) 336-346. https://doi.org/10.1016/j.ribaf.2017.04.053.

[45] S. Saya, L.G. Pee, A. Kankanhalli, The impact of institutional influences on perceived technological characteristics and real options in cloud computing adoption, in: ICIS 2010 Proc. - Thirty First Int. Conf. Inf. Syst., Missouri, USA, 2010.

[46] A.K. Das, Skills development for SMEs: Mapping of key initiatives in India, Institutions Econ. 7 (2015) 120-143. https://doi.org/10.2139/ssrn.2499207.

[47] GEM, Global Entrepreneurship Monitor (GEM) report 2017-18, 2018.

[48] G. Singh, A. DeNoble, Views on Self-employment and personality- an exploratory study, J. Dev. Entrep. 8 (2003) 265-281. http://scholar.google.com/scholar?hl=en\&btnG=Search\&q=intitle:Views+on+Selfemployment+and+personality-+an+exploratory+study\#0. 
[49] S. Choo, M. Wong, Entrepreneurial intention: Triggers and barriers to new venture creations in Singapore, Singapore Manag. Rev. 28 (2006) 47-64.

[50] PM FME Scheme to Invest of Rs 35,000 Crore and 9 Lakh Skilled Employment: Harsimrat Kaur Badal, (2020). https://smestreet.in/limelight/pm-fme-scheme-to-invest-of-rs-35000-crore-and-9-lakh-skilledemployment-harsimrat-kaur-badal/.

[51] J. Agarwal, Women entrepreneurship and innovations: evidencefFrom India, Res. J. Soc. Sci. Manag. 8 (2019) 64-68.

[52] A.K. Marg, Women entrepreneurship: Transforming from domestic household to financial independence, (2012) 1-38.

[53] MSME Definition Further Revised to Energise MSMEs With Entire Gamut of 'Atmanirbhar Bharat Package,' (2020). https://smestreet.in/limelight/msme-definition-further-revised-to-energise-msmeswith-entire-gamut-of-atmanirbhar-bharat-package/.

[54] A. Sevinç, Ş. Gür, T. Eren, Analysis of the difficulties of SMEs in industry 4.0 applications by analytical hierarchy process and analytical network process, Processes. $6 \quad$ (2018) 264. https://doi.org/10.3390/pr6120264.

[55] L.P. Fatti, Decision making for leaders: The analytical hierarchy process for decisions in a complex world, Eur. J. Oper. Res. 42 (1989) 107-109. https://doi.org/10.1016/0377-2217(89)90066-0.

[56] P.R. Drake, D. Myung Lee, M. Hussain, The lean and agile purchasing portfolio model, Supply Chain Manag. An Int. J. 18 (2013) 3-20. https://doi.org/10.1108/13598541311293140.

[57] F. Talib, Z. Rahman, Identification and prioritization of barriers to total quality management implementation in service industry: An analytic hierarchy process approach, TQM J. 27 (2015) 591-615. https://doi.org/10.1108/TQM-11-2013-0122.

[58] I.I. Karayalcin, The analytic hierarchy process: Planning, priority setting, resource allocation, Eur. J. Oper. Res. 9 (1982) 97-98. https://doi.org/10.1016/0377-2217(82)90022-4.

[59] T.L. Saaty, How to make a decision: The analytic hierarchy process, Eur. J. Oper. Res. 48 (1990) 9-26. https://doi.org/10.1016/0377-2217(90)90057-I.

[60] Global Innovation Index Report, 2019. https://www.wipo.int/publications/en/series/index.jsp?id=129. 